4. The serum potassium level was reduced in subjects suffering from diarrhoea, and severe hypokalaemia was present in four of the eleven fatal cases.

5. There was only limited correlation between the changes in total serum protein and albumin and subsidence of oedema.

We wish to thank Dr R. Cassel, his staff and Mrs D. van Jaarsveldt of the South African Institute for Medical Research for their technical assistance and Dr E. Kahn for helpful advice.

\title{
REFERENCES
}

Hansen, J. D. L. \& Brock, J. F. (1954). Lancet, 267, 477.

Leonsins, A. J. (1951). S. Afr. med. F. 25,5 I 5.

Varley, H. (1954). Practical Clinical Biochemistry, p. 338 . London: Heinemann.

Wolfson, W. Q., Cohn, C., Calvary, E. \& Ichiba, F. (1948). Amer. F. clin. Path. 18, 732.

\section{The effect of various levels of penicillin and chlortetracycline in the diet of fattening pigs}

\author{
By J. H. TAYLOR* \\ Agricultural Research Council Field Station, Compton, Berkshire \\ AND J. G. ROWELL \\ Agricultural Research Council Statistics Group, School of Agriculture, \\ University of Cambridge \\ (Received I4 Fuly 1956--Revised I5 Fanuary 1957)
}

The benefits to be derived from a dietary antibiotic supplement have been adequately demonstrated in pigs, poultry, calves and other animal species, but there are several factors that influence the magnitude of the antibiotic response. In this connexion the relation between the quantity of antibiotic administered and the growth response obtained requires further investigation.

Braude, Kon \& Porter (r953) suggested that the optimum level of inclusion of antibiotics in the diet of pigs probably lies within the range $5^{-15} \mathrm{~g} /$ ton food. Childs $\&$ Cuthbertson (1954) reported that under normal farm conditions in the British Isles levels of Io or $\mathrm{I} 5 \mathrm{~g}$ of procaine penicillin/ton food did not produce a significantly greater response than that obtained with a level of $5 \mathrm{~g}$.

Several reports have suggested, however, that with chlortetracycline and oxytetracycline higher levels of administration may be associated with a greater antibiotic response. Catron, Maddock, Speer \& Vohs (I95I) studied the effect of o, 5, I0, 20 and $40 \mathrm{mg}$ chlortetracycline hydrochloride/lb. ration and found that 20 and $40 \mathrm{mg}$

\footnotetext{
* Present address: Cyanamid of Great Britain Ltd, Bush House, Aldwych, London, W.C. 2.
} 
levels produced a greater improvement in growth rate and food conversion than 5 and Io mg levels. Perry \& Beeson (1952) gave levels of o, I, 2.5, 5.0 and $7.5 \mathrm{mg}$ chlortetracycline and oxytetracycline/lb. ration and found that with each the highest level of administration produced the greatest growth response. Wallace \& Gillespie (1955) compared the administration of $0,5,25$ and $50 \mathrm{mg}$ chlortetracycline hydrochloride/lb. food and showed that each increase in dose level produced an increase in rate of growth; during the first 8 weeks of life this increase was associated with a slight improvement in food utilization.

The purposes of the experiments reported here were to compare responses obtained with a wide range of levels of administration of penicillin and chlortetracycline and to compare the effectiveness of the two antibiotics at each level.

\section{EXPERIMENTAL}

\section{Plan of experiment}

Three experiments were carried out at the Agricultural Research Council Field Station at Compton and involved a total of 279 pigs. The starting dates for these experiments were September 1953 (Exp. I), February 1954 (Exp. 2) and July to September 1954 (Exp. 3); it was not possible to begin simultaneously with all the treatment groups in Exp. 3. In Exps. I and 2, levels of $0,2,4,8,16,32$ and $128 \mathrm{~g}$ of penicillin and of chlortetracycline were administered per ton food. In Exp. 3 additional levels of 64 and $256 \mathrm{~g}$ of each antibiotic were included, as the previous experiments suggested that the maximum growth response might not have been achieved at a level of $128 \mathrm{~g} /$ ton. There were not enough pigs available for all treatments to be tested at one time, so each experiment was divided into a number of blocks. In Exp. I, each block consisted of five pens in three housing units and in Exps. 2 and 3, each block consisted of six pens in two housing units; the allocation of treatments to housing units is shown in Table $\mathbf{I}$. The pigs in each block were allocated to treatments so that

\section{Table I. Allocation of treatments to blocks of litter-mate pigs and to housing units}

\begin{tabular}{|c|c|c|c|c|c|c|c|}
\hline \multirow{2}{*}{$\begin{array}{c}\text { Exp. } \\
\text { no. } \\
\text { I }\end{array}$} & \multirow{2}{*}{$\begin{array}{l}\text { Slaughter } \\
\text { weight } \\
\text { (lb.) } \\
200-210\end{array}$} & \multirow{2}{*}{$\begin{array}{c}\text { No. of } \\
\text { pigs/ } \\
\text { treatment } \\
5\end{array}$} & \multirow{2}{*}{$\begin{array}{l}\text { Block } \\
\text { no. } \\
\text { I } \\
\text { II } \\
\text { III }\end{array}$} & \multirow{2}{*}{$\begin{array}{c}\text { Initial } \\
\text { weight } \\
\text { (lb.) } \\
49^{\circ} \text { I } \\
35^{\circ} 8 \\
39^{\circ} \circ\end{array}$} & \multicolumn{3}{|c|}{ Allocation of treatments to housing units } \\
\hline & & & & & $\begin{array}{l}\mathrm{C} \\
\mathrm{C} \\
\mathrm{C}\end{array}$ & $\begin{array}{l}\mathrm{A}_{2}, \mathrm{P}_{2} \\
\mathrm{~A}_{8}, \mathrm{P}_{8} \\
\mathrm{~A}_{32}, \mathrm{P}_{32}\end{array}$ & $\begin{array}{l}\mathrm{A}_{4}, \mathrm{P}_{4} \\
\mathrm{~A}_{16}, \mathrm{P}_{16} \\
\mathrm{~A}_{128}, \mathrm{P}_{128}\end{array}$ \\
\hline 2 & 120 & $5^{*}$ & $\begin{array}{l}\text { I } \\
\text { II } \\
\text { III }\end{array}$ & $\begin{array}{l}41 \cdot 4 \\
45 \cdot 1 \\
3^{8 \cdot 7}\end{array}$ & $\begin{array}{l}\mathrm{C}, \mathrm{A}_{2}, \mathrm{P}_{2} \\
\mathrm{C}, \mathrm{A}_{4}, \mathrm{P}_{4} \\
\mathrm{C}, \mathrm{A}_{16}, \mathrm{P}_{16}\end{array}$ & $\begin{array}{l}\mathrm{C}, \mathrm{A}_{8}, \mathrm{P}_{8} \\
\mathrm{C}, \mathrm{A}_{12} 8, \mathrm{P}_{128} \\
\mathrm{C}, \mathrm{A}_{32}, \mathrm{P}_{32}\end{array}$ & - \\
\hline 3 & 120 & 5 & $\begin{array}{l}\text { I } \\
\text { II } \\
\text { III } \\
\text { IV }\end{array}$ & $\begin{array}{l}43 \cdot 6 \\
45 \cdot 9 \\
45 \cdot 2 \\
39 \cdot 7\end{array}$ & $\begin{array}{l}\mathrm{C}, \mathrm{A}_{2}, \mathrm{P}_{2} \\
\mathrm{C}, \mathrm{A}_{4}, \mathrm{P}_{4} \\
\mathrm{C}, \mathrm{A}_{8}, \mathrm{P}_{8} \\
\mathrm{C}, \mathrm{A}_{1} 6, \mathrm{P}_{1} 6\end{array}$ & $\begin{array}{l}\text { C, } \mathrm{A}_{32}, \mathrm{P}_{32} \\
\text { C, } \mathrm{A}_{64}, \mathrm{P}_{4} \\
\mathrm{C}, \mathrm{A}_{128}, \mathrm{P}_{128} \\
\mathrm{C}, \mathrm{A}_{25}, \mathrm{P}_{256}\end{array}$ & - \\
\hline
\end{tabular}

$\mathrm{C}$ denotes control, $\mathrm{A}$ aureomycin (chlortetracycline) and $\mathrm{P}$ penicillin; the numbers following $\mathrm{A}$ and $P$ show the dose $(\mathrm{g} / \mathrm{ton})$ of the antibiotic.

* Owing to shortage of pigs, there were only four in the control pens of Exp. 2 . 
there were the same number from a given litter in each treatment; initial weight and sex were balanced as far as possible. 'The animals were 8-Io weeks old at the beginning of the experiment. In Exp. I they were slaughtered at $200-210 \mathrm{lb}$. live weight and in Exps. 2 and 3 at about $r 20 \mathrm{lb}$. live weight.

\section{Pigs and their management}

The pigs used were pedigree Large Whites and came from stock having a low disease level. Each treatment group was housed in a self-contained, concrete-lined loose box which had been thoroughly scrubbed and 'sterilized' with a steam jet immediately before housing the experimental animals. The standard of health was generally high with the exception of some lameness diagnosed as arthritis. The pigs were fed twice daily with as much food in a wet state as could be eaten in half an hour. The ration was based on a diet recommended by the Ministry of Agriculture and Fisheries (1953), details of which can be seen in Table 2.

Table 2. Basal diet used in all experiments (parts by weight)

$\begin{array}{lcc}\text { Ingredient } & \begin{array}{c}\text { From weaning } \\ \text { to I8 weeks } \\ \text { of age }\end{array} & \begin{array}{c}\text { Over 18 weeks } \\ \text { of age }\end{array} \\ \text { Weatings* } & 25 & 25 \\ \text { Barley meal } & 55 & 60 \\ \text { Extracted groundnut meal (decorticated) } & 5 & 8 \\ \text { Dried-grass meal } & 5 & 5 \\ \text { White-fish meal } & 7 & 0 \\ \text { Mineralst } & 2 & 2 \\ \text { Cod-liver oil } & \text { I } & \circ\end{array}$

* Fine wheat offal.

$\uparrow$ Ground chalk 3, steamed bone-flour I, salt I parts.

Penicillin was added to the appropriate rations as procaine penicillin $\mathrm{G}$ and chlortetracycline as the hydrochloride. The supplements were incorporated into the rations as described by Gordon $\&$ Taylor (r 953 ). The pigs were individually weighed each week and the total amount of food consumed in each pen was recorded weekly. The pigs were group-fed, so that individual food-consumption figures were not available.

\section{Biometrical methods}

Growth rate and food conversion were examined statistically. Corrections were made to growth rate to allow for variations in initial and final weight.

To investigate differences between antibiotics within dose levels, a split-plot type of analysis was carried out in which whole plots corresponded to housing units and split plots corresponded to the two pens, within the housing units, in which the pigs were fed on diets supplemented with the same level of penicillin or chlortetracycline.

The effect of housing units was studied by comparing the mean square between controls within blocks (available from Exps. 2 and 3 ) with the mean square between 
pens within housing units as estimated from the split-plot analysis. These mean squares were as follows:

$\begin{array}{lccc} & \begin{array}{c}\text { Degrees of } \\ \text { freedom }\end{array} & \text { Growth rate } & \text { Food conversion } \\ \text { Between housing units } & 7 & 0.00238 & 0.0235 \\ \text { Between pens, within units } & 12 & 0.00387 & 0.0322\end{array}$

and suggest that the effect of housing unit on growth rate and food conversion was little, if at all, greater than the effect of pen.

In studying differences between doses, the effect of blocks was eliminated by expressing the observations for the pigs fed on supplemented diets as percentages of the mean for the control pigs in the appropriate block. Regressions of these figures on $\log$ dose were calculated for each antibiotic, the regressions being pooled and compared. Working with a log scale for dose means that the relationship between $\log$ dose and response must flatten out for low dose levels; observations for these levels were therefore given arbitrarily smaller weights.

RESULTS

The growth rates and food-conversion ratios for each experiment are given in Tables 3 and 4 .

Table 3. Mean growth rates of pigs fed on unsupplemented diets and on diets containing various levels of penicillin or chlortetracycline

\begin{tabular}{|c|c|c|c|c|c|c|c|c|c|c|c|}
\hline \multirow{2}{*}{$\begin{array}{l}\text { Exp. } \\
\text { no. }\end{array}$} & \multirow[b]{2}{*}{ Treatment } & \multirow{2}{*}{$\begin{array}{c}\text { Slaughter } \\
\text { weight } \\
\text { (lb.) }\end{array}$} & \multirow{2}{*}{$\begin{array}{l}\text { No. of } \\
\text { pigs/ } \\
\text { treat- } \\
\text { ment } \dagger\end{array}$} & \multicolumn{8}{|c|}{$\begin{array}{c}\text { Growth rate (lb./day) of pigs given antibiotic } \\
\text { supplement of ( } \mathrm{g} / \text { ton food })\end{array}$} \\
\hline & & & & 2 & 4 & 8 & 16 & 32 & 64 & 128 & 256 \\
\hline \multirow[t]{3}{*}{ I } & None* & $200-210$ & 5 & $I \cdot 67$ & $x \cdot 67$ & $\mathrm{I} \cdot 4 \mathrm{I}$ & $I \cdot 41$ & $I \cdot 45$ & - & $1 \cdot 45$ & - \\
\hline & Penicillin & & 5 & $I \cdot 66$ & $1 \cdot 59$ & $I \cdot 69$ & $\mathrm{I} \cdot 66$ & $\mathrm{I} \cdot 77$ & - & I.59 & - \\
\hline & $\begin{array}{l}\text { Chlortetra- } \\
\text { cycline }\end{array}$ & & 5 & I. 55 & 1.67 & $I \cdot 60$ & $I \cdot 67$ & $I \cdot 65$ & - & $I \cdot 74$ & 一 \\
\hline \multirow[t]{3}{*}{2} & None & I 20 & 4 & $I \cdot 04$ & I.09 & 1.03 & $\mathrm{I} \cdot \mathrm{I} 4$ & $I \cdot I 3$ & - & I. $0_{4}$ & — \\
\hline & Penicillin & & 5 & $\mathrm{I} \cdot 03$ & $I \cdot 2 I$ & $I \cdot I 5$ & $I \cdot 2 I$ & $I \cdot I 4$ & - & $I \cdot 2$ I & 一 \\
\hline & $\begin{array}{l}\text { Chlortetra- } \\
\text { cycline }\end{array}$ & & 5 & $I \cdot 14$ & I.09 & I'I 4 & $I \cdot 14$ & $I \cdot 17$ & - & $\mathrm{I} \cdot 32$ & - \\
\hline \multirow[t]{3}{*}{3} & None & 120 & 5 & $\mathrm{I} \cdot 32$ & $\mathrm{I} \cdot \mathrm{I} 4$ & $r \cdot 26$ & $1 \cdot 23$ & I. 37 & $\mathrm{I} \cdot 24$ & I 35 & $\mathrm{I} \cdot 33$ \\
\hline & Penicillin & & 5 & $\mathrm{I} \cdot 35$ & $x \cdot 3^{8}$ & $1 \cdot 30$ & +27 & $\begin{array}{l}2.52 \\
I \cdot 55\end{array}$ & $1 \cdot 37$ & 1.40 & $\begin{array}{l}33 \\
1 \cdot 56\end{array}$ \\
\hline & $\begin{array}{l}\text { Chlortetra- } \\
\text { cycline }\end{array}$ & & 5 & $\begin{array}{l}\text { I. } \\
\text { I.45 }\end{array}$ & $I \cdot 36$ & $\mathrm{I} \cdot 24$ & $\mathrm{I} \cdot 29$ & $\begin{array}{r}1.52 \\
\end{array}$ & $\mathrm{I} \cdot 42$ & $\begin{array}{r}14 \\
1 \cdot 35\end{array}$ & I. 54 \\
\hline
\end{tabular}

* In Exp. I there were only three control pens, one for each of three blocks in which the doses were 2 and 4,8 and 16 , and 32 and $128 \mathrm{~g} /$ ton food.

$\uparrow$ Initial weights are given in Table $\mathbf{I}$.

The effects of penicillin and chlortetracycline on growth rate and food conversion did not differ significantly at any level of administration. The regressions on log dose were significant $(P<0.05)$ for both growth rate and food conversion, and the differences of regressions between antibiotics were not significant for either measurement. Figs. I and 2 indicate the improvement in growth rate and food conversion at each dose level. 
Table 4. Mean food-conversion ratios of pigs fed on unsupplemented diets and diets containing various levels of penicillin or chlortetracycline

\begin{tabular}{|c|c|c|c|c|c|c|c|c|c|c|c|}
\hline \multirow{2}{*}{$\begin{array}{l}\text { Exp. } \\
\text { no. }\end{array}$} & \multirow[b]{2}{*}{ Treatment } & \multirow{2}{*}{$\begin{array}{l}\text { Slaughter } \\
\text { weight } \\
\text { (lb.) }\end{array}$} & \multirow{2}{*}{$\begin{array}{l}\text { No. of } \\
\text { pigs/ } \\
\text { treat- } \\
\text { ment } \dagger\end{array}$} & \multicolumn{8}{|c|}{$\begin{array}{c}\text { Food-conversion ratio (lb. food/lb. live-weight } \\
\text { increase) of pigs given antibiotic } \\
\text { supplement of ( } \mathrm{g} / \text { ton food) }\end{array}$} \\
\hline & & & & 2 & 4 & 8 & $x 6$ & 32 & 64 & 128 & 256 \\
\hline $\mathbf{I}$ & $\begin{array}{l}\text { None* } \\
\text { Penicillin } \\
\text { Chlortetra- } \\
\text { cycline }\end{array}$ & $200-210$ & $\begin{array}{l}5 \\
5 \\
5\end{array}$ & $\begin{array}{l}3 \cdot 64 \\
3 \cdot 63 \\
3 \cdot 86\end{array}$ & $\begin{array}{l}3.64 \\
3.72 \\
3.59\end{array}$ & $\begin{array}{l}4.17 \\
3.90 \\
3 \cdot 91\end{array}$ & $\begin{array}{l}4.17 \\
3.57 \\
3 \cdot 67\end{array}$ & $\begin{array}{l}4.00 \\
3.47 \\
3.72\end{array}$ & - & $\begin{array}{l}4 \cdot 00 \\
3 \cdot 62 \\
3 \cdot 85\end{array}$ & 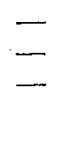 \\
\hline 2 & $\begin{array}{l}\text { None } \\
\text { Penicillin } \\
\text { Chlortetra- } \\
\text { cycline }\end{array}$ & 120 & $\begin{array}{l}4 \\
5 \\
5\end{array}$ & $\begin{array}{l}4 \cdot 38 \\
4 \cdot 07 \\
3 \cdot 27\end{array}$ & $\begin{array}{l}3.99 \\
3.61 \\
3.61\end{array}$ & $\begin{array}{l}4 \cdot 26 \\
3 \cdot 60 \\
3 \cdot 74\end{array}$ & $\begin{array}{l}3 \cdot 90 \\
3 \cdot 49 \\
3 \cdot 74\end{array}$ & $\begin{array}{l}3 \cdot 93 \\
3.75 \\
3 \cdot 83\end{array}$ & - & $\begin{array}{l}3.89 \\
3.34 \\
3.05\end{array}$ & - \\
\hline 3 & $\begin{array}{l}\text { None } \\
\text { Penicillin } \\
\text { Chlortetra- } \\
\text { cycline }\end{array}$ & 120 & $\begin{array}{l}5 \\
5 \\
5\end{array}$ & $\begin{array}{l}3 \cdot 24 \\
3 \cdot 24 \\
2 \cdot 97\end{array}$ & $\begin{array}{l}3 \cdot 64 \\
2 \cdot 70 \\
2 \cdot 75\end{array}$ & $\begin{array}{l}3 \cdot 39 \\
3 \cdot 17 \\
3 \cdot 39\end{array}$ & $\begin{array}{l}3 \cdot 64 \\
3 \cdot 31 \\
3 \cdot 38\end{array}$ & $\begin{array}{l}3.06 \\
2.65 \\
2.67\end{array}$ & $\begin{array}{l}3 \cdot 31 \\
2 \cdot 97 \\
2 \cdot 61\end{array}$ & $\begin{array}{l}3 \cdot 02 \\
2 \cdot 91 \\
3 \cdot 05\end{array}$ & $\begin{array}{l}3 \cdot 48 \\
2 \cdot 77 \\
3 \cdot 01\end{array}$ \\
\hline
\end{tabular}

* In Exp. I there were only three control pens, one for each of three blocks in which the doses were 2 and 4,8 and 16 , and 32 and $128 \mathrm{~g} /$ ton food.

$\dagger$ Initial weights are given in Table $\mathrm{I}$.

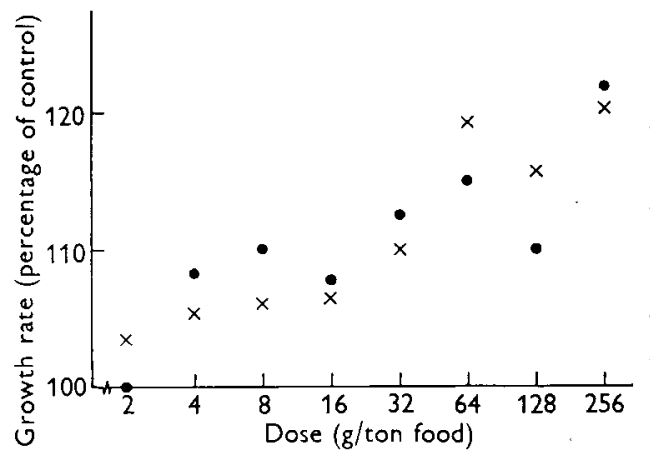

Fig. I

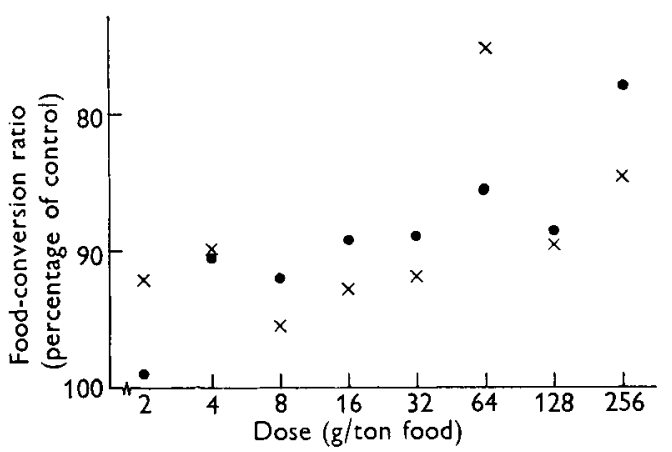

Fig. 2

Fig. I. Growth rate of pigs fed on diets containing various levels of penicillin or chlortetracycline, expressed as a percentage of that of the controls, and plotted against log dose. $\bullet$, penicillin; $x$, chlortetracycline.

Fig. 2. Food-conversion ratio of pigs fed on diets containing various levels of penicillin or chlortetracycline, expressed as a percentage of that of the controls, and plotted against log dose. $\bullet$, penicillin; $x$, chlortetracycline.

\section{DISCUSSION}

The results suggest that the improvement in growth rate and food conversion increases with the dose level of antibiotic, at least within the range $2-256 \mathrm{~g} / \mathrm{ton}$ food, and that the rate of increase is substantially the same for penicillin and chlortetracycline. Catron et al. (I95I) carried out an investigation using several levels of chlortetracycline, and their results are in general agreement with those discussed here. The present investigation also confirms the result of the trials sponsored by the Agricultural 
Research Council (1953) that there is no significant difference between the effects of penicillin and chlortetracycline.

In interpreting these results consideration should be given to the associated 'disease level' present; this factor is known to cause wide variation in response to antibiotics. In our experiments the animal accommodation was very thoroughly cleaned before the beginning of the experiment, and the buildings had housed pigs for only a short time before the experiment. Under practical farming conditions with the usual degree of environmental contamination it has been observed that the broad-spectrum antibiotics may be of most value. Thus Braude, Wallace \& Cunha (1953) suggested that under normal conditions chlortetracycline may be some $30 \%$ more effective than penicillin in increasing the rate of growth of pigs.

\section{SUMMARY}

I. Experiments were carried out to investigate the effect on the rate of growth and food-conversion ratio of fattening pigs of various levels of penicillin and chlortetracycline in their diet. Rations were used in which antibiotic was added at the rate of $0,2,4,8,16,32,64,128$ and $256 \mathrm{~g} /$ ton food. The experiments were replicated three times and involved 279 pigs.

2. The regressions of growth rate and of food conversion on log dose were significant; the differences of the regressions between antibiotics were not significant.

3. Neither growth rate nor food conversion differed significantly between antibiotics at any dose level.

The authors wish to acknowledge the continual interest and advice of Dr W. S. Gordon, C.B.E. They are also grateful to Glaxo Laboratories Ltd for supplying the procaine penicillin $\mathrm{G}$ and to Cyanamid of Great Britain Ltd for supplying the chlortetracycline hydrochloride.

\section{REFERENCES}

Agricultural Research Council (1953). Rep. agric. Res. Coun. no. 13.

Braude, R., Kon, S. K. \& Porter, J. W. G. (1953). Nutr. Abstr. Rev. 23, 473.

Braude, R., Wallace, H. D. \& Cunha, T. J. (1953). Antibiot. E Chemother. 3, 271.

Catron, D. V., Maddock, H. M., Speer, V. C. \& Vohs, R. L. (195I). Antibiot. E' Chemother. I, 3 I.

Childs, G. A. \& Cuthbertson, W. F. J. (r954). F. Sci. Fd Agric. 5, 330.

Gordon, W. S. \& Taylor, J. H. (1953). Vet. Rec. 65, 838 .

Ministry of Agriculture and Fisheries (1953). Adv. Leafl. Minist. Agric. Fish., Lond., no. I04.

Perry, T. W., \& Beeson, W. M. (1952). Ұ. Anim. Sci. 11, 773.

Wallace, H. D. \& Gillespie, L. (1955). Florida agric. Exp. Sta. 55-2. (Mimeo.) 